Short Research Article

\title{
Yield Potential, Economics and Nutrient Uptake of Rabi Sweet Corn (Zea mays saccharata) as Influenced by Varying Plant Densities and Nitrogen Rates
}

\author{
Sandya N. R. , G. Subbaiah and CH. Pulla Rao
}

Dept. of Agronomy, Agricultural College, Angrau, Bapatla, Andhra Pradesh (522 101), India

\section{Article History}

Manuscript No. AR1559b

Received in $15^{\text {th }}$ March, 2016

Received in revised form $28^{\text {th }}$ March, 2016

Accepted in final form $2^{\text {nd }}$ April, 2016

\section{Correspondence to}

"E-mail: sandhyaneelaram@gmail.com

\section{Keywords}

Sweet corn, plant densities, nitrogen, yield, economics, nutrient uptake

\begin{abstract}
A field experiment was conducted during rabi, 2013-14 on clay loam soil of Agriculture College Farm, Bapatla, Andhra Pradesh, India to study the influence of plant densities and nitrogen rates on yield, economics and nutrient uptake of sweet corn (Zea mays saccharata). The treatments consisted of combination of three planting densities $\left(\mathrm{P}_{1}\right.$ : 1,11,111 plants ha- $\mathrm{P}_{2}: 83,333$ plants ha- ${ }^{-1}$ and $\mathrm{P}_{3}: 66,666$ plants ha $\left.{ }^{-1}\right)$ and four nitrogen levels $\left(\mathrm{N}_{1}: 120 \mathrm{~kg} \mathrm{~N} \mathrm{ha}^{-1}, \mathrm{~N}_{2}: 170 \mathrm{~kg} \mathrm{~N} \mathrm{ha}^{-1}, \mathrm{~N}_{3}: 220 \mathrm{~kg} \mathrm{~N}^{-1}\right.$ and $\left.\mathrm{N}_{4}: 270 \mathrm{~kg} \mathrm{~N} \mathrm{ha}^{-1}\right)$. Significantly higher value of yield attributes were noticed with planting density of 66,666 plants ha ${ }^{-1}$ and nitrogen level of $270 \mathrm{~kg} \mathrm{ha}^{-1}$. Significant green cob and green fodder yield of sweet corn were recorded at planting density of 83,333 plants ha ${ }^{-1}$ and $1,11,111$ plants ha-1 respectively with the application of $270 \mathrm{~kg} \mathrm{~N} \mathrm{ha}^{-1}$. The maximum nutrient uptake by sweet corn crop and stover was noticed with planting density of 83,333 plants ha ${ }^{-1}$ and $1,11,111$ plants ha $^{-1}$ respectively with the application of $270 \mathrm{~kg}$ $\mathrm{N} \mathrm{ha}^{-1}$. The highest net returns and B:C ratio were recorded with application of $270 \mathrm{~kg}$ $\mathrm{N} \mathrm{ha}^{-1}$ at planting density of 83,333 plants ha ${ }^{-1}$ over all other treatment combinations. Hence, plant density of 83,333 plants ha ${ }^{-1}$ with nitrogen level of $270 \mathrm{~kg} \mathrm{~N}^{-1}$ hould be adopted to obtain the maximum nutrient uptake, green cob yield and net profit from sweet corn in Krishna Agro-climatic zone of Andhra Pradesh.
\end{abstract}

\section{Introduction}

Maize is one of the cultivated grain-cum-fodder crops with tremendous yield potential. Sweet corn (Zea mays L. saccharata) is a mutant type of maize gaining popularity both in rural and urban areas because of its higher sugar content (14-20\%) and low starch content with delicious taste (Sahoo and Mahapatra, 2007). It occupies an area of $11.98 \mathrm{mha}$ producing $21.57 \mathrm{mt}$ in India (Area and production of Maize in India, GoI Statistics, 2012-13). Andhra Pradesh contributes $22 \%$ of the total India's maize production. The sweet corn industry is expanding because of increasing domestic consumption, export development and import replacement.

It grows quickly and is considered as a valuable rotational crop as well as the farming operations can be mechanized. Most of the sweet corn is grown for the processing sector ending up on the super market shelves as products which include canned kernels, frozen cobetts and frozen kernels. Sweet corn can be harvested within 80 to 90 days after sowing and thereby field duration could be reduced earlier by 35 to 45 days compared to normal grain corn. This earliness facilitates to include in the intensive cropping programmes to increase the overall cropping intensity in a year (Oktem, 2005). Since there is limited scope to increase the area under sweet corn cultivation because of competition from other cereals and commercial crops, the only alternative is through enhancement of productivity by various management factors. The optimum plant density is an important factor for intercepting sunlight for harvesting maximum photosynthesis besides, efficient use of plant nutrients and soil moisture. Nitrogen is the essential constituent of chlorophyll, protoplasm and enzymes. Further, it governs utilization of phosphorus and potassium. It is an important factor for better vegetative growth and boosting up the yield of cereals. However, no systematic research has been conducted to develop suitable site and situation specific production technology for sweet corn (Kumar, 2009). Keeping these points in view, the present investigation was under taken to assess the optimum plant density with fertilizer schedule for higher yields and profits.

\section{Materials and Methods}

A field experiment was conducted on clay loam soil of Agricultural College Farm, Bapatla during kharif 2013-14. 
Bapatla, Andhra Pradesh, India is located at $15^{\circ} 55^{\prime} \mathrm{N}$ latitude, $80^{\circ} 30^{\prime} \mathrm{E}$ longitude with an altitude of $4.29 \mathrm{~m}$ above the mean sea level and about $8 \mathrm{~km}$ away from the Bay of Bengal in the Krishna Agro-climatic zone of Andhra Pradesh, India. A negligible rainfall (3.3 $\mathrm{mm}$ ) was received during the entire crop growth period. The mean maximum and minimum temperatures were of $30.3^{\circ} \mathrm{C}$ and $18.7^{\circ} \mathrm{C}$ respectively, with a range of 29.3 to $33^{\circ} \mathrm{C}$ and 16.6 to $20.9{ }^{\circ} \mathrm{C}$, respectively with mean relative humidity of $76.7 \%$ during the period of experimentation. The treatments consisted of combination of three planting densities $\left(\mathrm{P}_{1}: 1,11,111\right.$ plants ha-1 $\mathrm{P}_{2}: 83,333$ plants ha-1 and $\mathrm{P}_{3}: 66,666$ plants $\left.\mathrm{ha}^{-1}\right)$ and four nitrogen levels $\left(\mathrm{N}_{1}: 120 \mathrm{~kg} \mathrm{~N} \mathrm{ha}^{-1}, \mathrm{~N}_{2}\right.$ : $170 \mathrm{~kg} \mathrm{~N} \mathrm{ha}^{-1}, \mathrm{~N}_{3}: 220 \mathrm{~kg} \mathrm{~N} \mathrm{ha}^{-1}$ and $\mathrm{N}_{4}: 270 \mathrm{~kg} \mathrm{~N} \mathrm{ha}^{-1}$ ). The experiment was laid out in randomized block design with factorial concept design with three replications. The soil of the experimental site was slightly alkaline in reaction with $\mathrm{pH} 7.8$, low in organic carbon $(0.6 \%)$, low in available nitrogen (198.6 $\left.\mathrm{kg} \mathrm{N} \mathrm{ha}^{-1}\right)$ and medium in phosphorous $\left(23 \mathrm{~kg} \mathrm{P}_{2} \mathrm{O}_{5} \mathrm{ha}^{-1}\right)$ and high in available potassium $\left(747 \mathrm{~kg} \mathrm{~K}_{2} \mathrm{O} \mathrm{ha}^{-1}\right)$. Bold and healthy seedsof sweet corn hybrid 'Sugar-75' were sown at a depth of 2-3 cm sown on 16.12.2013 as per treatments and harvested on 14.03.2014. Nitrogen was applied in the form of urea $(46 \% \mathrm{~N})$ as per the treatments in 3 splits i.e., $1 / 4$ at the time of sowing, $1 / 2$ at knee high stage and $1 / 4$ at tasseling stage. The uniform dose of $60 \mathrm{~kg} \mathrm{P}_{2} \mathrm{O}_{5}$ and $50 \mathrm{~kg} \mathrm{~K}_{2} \mathrm{O} \mathrm{ha}^{-1}$ was applied in the form of single superphosphate $\left(16 \% \mathrm{P}_{2} \mathrm{O}_{5}\right)$ and muriate of potash $(60 \%$ $\mathrm{K}_{2} \mathrm{O}$ ) respectively, at the time of sowing. Two hand weedings were done during entire crop growth period twice at 15 DAS and 30 DAS. A total of six irrigations were given during the entire crop growth period. Prophylactic measures were taken up against stem borer (Spodoptera litura) by spraying a combination of chlorpyriphos and dichlorvos@1.5 ml L-1 and $1 \mathrm{ml} \mathrm{L}^{-1}$ respectively. As a precautionary measure, whorl application of Carbofuran granules@10 kg ha-1 was done to protect the crop against stem borer. Five random plants were sampled from each plot for observing plant height, drymatter production/plant and yield attributes. Economics were calculated on the basis of prevailing market prices of inputs and produce. Of leaves and stem (shoot), nitrogen and phosphorus were estimated by Micro Kjeldahl's method, Vanadomolybdate phosphoric yellow colour method (Jackson, 1973) respectively and potassium was determined by Flame photometer method (Jackson, 1973) and it was expressed in per cent.Nutrient uptake based on nutrient content of plant was calculated by using the formula given below:

Nutrient uptake $\left(\mathrm{kg} \mathrm{ha}^{-1}\right)=\frac{\begin{array}{c}\text { Nutrient } \\ \text { concentration }(\%)\end{array}{\text { matter }\left(\mathrm{kg} \mathrm{ha}^{-1}\right)}^{\text {Weight of dry }}}{100}$

\section{Results and Discussion}

\subsection{Yield attributes}

Significantly longer cobs $(17.6 \mathrm{~cm})$ and higher number of cobs plant $^{-1}(1.12)$ were observed at 66,666 plants ha ${ }^{-1}$ which was on a par with that of 83,333 plants $\mathrm{ha}^{-1}$ but both of them differed significantly from $1,11,111$ plants $\mathrm{ha}^{-1}$ (Table 1 ). Significantly higher number of kernel rows $\operatorname{cob}^{-1}(17.7)$ and higher fresh kernel weight (30.7) were produced by sweet corn sown at lower plant density of 66,666 plants $\mathrm{ha}^{-1}$ when compared to remaining two plant densities. Plants at lower density might have efficiently utilized all the growth resources with low degree of inter plant competition which, in turn accumulated higher levels of assimilates and efficiently translocated to the sink compared to higher planting density of 1,11,111 plants $\mathrm{ha}^{-1}$ with minimum light interception and high competition for moisture and nutrients which resulted in low photosynthate accumulation.

The cob length $(17.9 \mathrm{~cm})$ and maximum fresh kernel weight

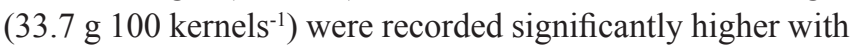
$270 \mathrm{~kg} \mathrm{~N} \mathrm{ha}^{-1}$ compared to other $\mathrm{N}$ levels tested. The maximum number of kernels rows $\operatorname{cob}^{-1}$ (17.7) and cobs plant ${ }^{-1}$ (1.13) were recorded with $270 \mathrm{~kg} \mathrm{~N} \mathrm{ha}^{-1}$ which was on a par with that of $220 \mathrm{~kg} \mathrm{~N} \mathrm{ha}^{-1}$ and both were significantly superior to that of $120 \mathrm{~kg} \mathrm{ha}^{-1}$. It might be probably due to favourable effect on cell enlargement in production of larger leaves and improving photosynthetic efficiency of plants through stress free environment created by adequate supply of nutrients with application of $270 \mathrm{~kg} \mathrm{~N} \mathrm{ha}^{-1}$. Similar results were also reported by Sahoo and Mahapatra (2007).

\subsection{Cob and fodder Yield}

The higher green cob yield (14601 kg ha-1) was recorded with 83,333 plants ha-1 $\left(\mathrm{P}_{2}\right)$ and the lower green cob yield $(9853 \mathrm{~kg}$ ha $^{-1}$ ) was with $1,11,111$ plants ha- ${ }^{-1}\left(\mathrm{P}_{1}\right)$. High plant population might have increased competition between plants and created a stress environment for plant growth at higher planting densities which consequently lowered down the yield at 1,11,111 plants $\mathrm{ha}^{-1}$. The green cob yield recorded with application of 270 $\mathrm{kg} \mathrm{N} \mathrm{ha-1}$ was significantly higher (14114 $\mathrm{kg} \mathrm{ha}^{-1}$ ) over rest of the nitrogen levels. The positive response to higher level of nitrogen on green cob yield could be ascribed to overall improvement in crop growth that enabled the plant to absorb more nutrients and moisture which might have enabled the plant to accumulate more quantities of photosynthates in the sink. Similar findings of response of sweet corn to higher nitrogen levels were reported by Bhatt (2012) and (Singh et al., 2012).

The green fodder yield increased significantly with increase in planting densities. Significantly higher green fodder yield (18997 $\mathrm{kg} \mathrm{ha}^{-1}$ ) was produced by $1,11,111$ plants ha ${ }^{-1}$ which was probably due to more number of plants unit area ${ }^{-1}$. 
Application of $270 \mathrm{~kg} \mathrm{~N}^{-1}$ significantly enhanced the green fodder yield (18967 kg ha-1) over rest of the nitrogen levels. These results are in full agreement with the findings of (Arvadiya et al., 2012); Kumar (2009); Bhatt (2012); (Singh et al., 2012).

\subsection{Nutrient uptake}

Nutrient uptake is the function of nutrient concentration and dry matter yield of the crop.

\subsubsection{Nitrogen Uptake}

The uptake of nitrogen by grain with a plant density of 83,333 ha $^{-1}$ was significantly superior over 66,666 plants $_{\text {ha }}{ }^{-1}$, while it was on a par with 1,11,111 plants ha-1. The increase in nitrogen uptake of sweet corn grain at harvest with 83,333 plants ha ${ }^{-1}$ over 66,666 plants ha ${ }^{-1}$ was to the tune of $27.2 \%$. The higher green cob yield at 83,333 plants ha $^{-1}$ resulted in the highest nutrient uptake. Nitrogen uptake by stover increased with

\begin{tabular}{|c|c|c|c|c|c|c|}
\hline Treatment & $\begin{array}{l}\text { Number of } \\
\text { cobs plant }^{-1}\end{array}$ & $\begin{array}{l}\text { Cob length } \\
\quad(\mathrm{cm})\end{array}$ & $\begin{array}{c}\text { Number of } \\
\text { kernel rows } \\
\text { cob }^{-1}\end{array}$ & $\begin{array}{l}\text { Fresh kernel } \\
\text { wt. (g } 100^{-1} \\
\text { kernels) }\end{array}$ & $\begin{array}{c}\text { Green cob } \\
\text { yield } \\
\left(\mathrm{kg} \mathrm{ha}^{-1}\right)\end{array}$ & $\begin{array}{c}\text { Green fodder } \\
\text { yield } \\
\left(\mathrm{kg} \mathrm{ha}^{-1}\right)\end{array}$ \\
\hline \multicolumn{7}{|c|}{ Plant populations ( plants ha ${ }^{-1}$ ) } \\
\hline $\mathrm{P}_{1}-1,11,111\left(45 \times 20 \mathrm{~cm}^{2}\right)$ & 1.02 & 16.2 & 15.9 & 27.4 & 9853 & 18997 \\
\hline$P_{2}-83,333\left(60 \times 20 \mathrm{~cm}^{2}\right)$ & 1.05 & 17.1 & 16.9 & 29.2 & 14601 & 16245 \\
\hline$P_{3}-66,666\left(75 \times 20 \mathrm{~cm}^{2}\right)$ & 1.11 & 17.6 & 17.7 & 30.7 & 10416 & 14441 \\
\hline $\mathrm{SEm} \pm$ & 0.02 & 0.2 & 0.26 & 0.39 & 339.1 & 537.7 \\
\hline $\mathrm{CD}(p=0.05)$ & 0.07 & 0.6 & 0.78 & 1.15 & 994 & 1577 \\
\hline \multicolumn{7}{|l|}{ Nitrogen levels $\left(\mathrm{kg} \mathrm{ha}^{-1}\right)$} \\
\hline $\mathrm{N}_{1}-120$ & 1.00 & 16.1 & 15.8 & 25 & 8875 & 13970 \\
\hline $\mathrm{N}_{2}-170$ & 1.04 & 16.7 & 16.3 & 27.4 & 10846 & 15927 \\
\hline $\mathrm{N}_{3}-220$ & 1.07 & 17.2 & 17.4 & 30.3 & 12659 & 17380 \\
\hline $\mathrm{N}_{4}-270$ & 1.13 & 17.9 & 17.7 & 33.7 & 14114 & 18967 \\
\hline $\mathrm{SEm} \pm$ & 0.03 & 0.2 & 0.3 & 0.45 & 391.5 & 620.8 \\
\hline $\mathrm{CD}(p=0.05)$ & 0.08 & 0.6 & 0.9 & 1.32 & 1148 & 1821 \\
\hline \multicolumn{7}{|l|}{ Interaction $(\mathrm{P} \times \mathrm{N})$} \\
\hline $\mathrm{SEm} \pm$ & 0.05 & 0.39 & 0.53 & 0.78 & 678.2 & 1075.4 \\
\hline $\mathrm{CD}(p=0.05)$ & NS & NS & NS & NS & NS & NS \\
\hline
\end{tabular}

each increase in planting density. The highest nitrogen uptake by stover $\left(64.35 \mathrm{~kg} \mathrm{ha}^{-1}\right)$ with 1,11,111 plants ha ${ }^{-1}$ was significantly superior to that of other two plant densities, which might be due to production of significantly the maximum fodder yield as was evident from Table 2 at planting density of 1,11,111 plants ha-1.

The increase in the level of nitrogen from 120 to $270 \mathrm{~kg} \mathrm{ha}^{-1}$ significantly influenced the nitrogen uptake. Significantly the highest nitrogen uptake (182.3 $\left.\mathrm{kg} \mathrm{ha}^{-1}\right)$ was recorded with application of $270 \mathrm{~kg} \mathrm{~N} \mathrm{ha}^{-1}$ compared to remaining doses. The increased uptake of nitrogen by the crop due to increasing levels of nitrogen might be due to increased green cob and green fodder yields. These results were consistent with findings of Sahoo and Mahapatra (2007); Kumar (2009); Bhatt (2012); (Singh et al., 2012).

\subsubsection{Phosphorus uptake}

Higher uptake of phosphorus observed with the plant density of 83,333 plants ha $^{-1}$ differed significantly over that of remaining two densities by grain at harvest . But, uptake of phosphorus by stover was recorded numerically high at 1,11,111 plants ha-1 due to higher fodder yield than other two plant densities tested.

The phosphorus uptake by sweet corn with the application of $270 \mathrm{~kg} \mathrm{~N} \mathrm{ha}^{-1}$ (40.2 $\mathrm{kg} \mathrm{ha}^{-1}$ ) was significantly superior to other nitrogen levels. This might be due to synergistic effect of $\mathrm{N}$ and $\mathrm{P}$ leading to higher yield and uptake of phosphorus as reported by Coldwell (1960). These results are in line with the findings of Sahoo and Mahapatra (2007); Bhatt (2012).

\subsubsection{Potassium uptake}

Higher potassium uptake was recorded with the plant density of 83,333 plants $\mathrm{ha}^{-1}\left(86,109 \mathrm{~kg} \mathrm{ha}^{-1}\right)$ and it differed significantly from the remaining two densities. The potassium uptake by sweet corn was significantly the highest $\left(137 \mathrm{~kg} \mathrm{ha}^{-1}\right)$ with the application of $270 \mathrm{~kg} \mathrm{~N} \mathrm{ha}^{-1}$, which was significantly superior to other nitrogen levels. This might be due to favourable effect of nitrogen on the uptake of potassium as well as increased green 
Table 2: Effect of plant densities and nitrogen rates on nutrient uptake of sweet corn

\begin{tabular}{|c|c|c|c|c|c|c|}
\hline \multirow[t]{2}{*}{ Treatment } & \multicolumn{2}{|c|}{ Nitrogen $\left(\mathrm{kg} \mathrm{ha}^{-1}\right)$} & \multicolumn{2}{|c|}{ Phosphorus $\left(\mathrm{kg} \mathrm{ha}^{-1}\right)$} & \multicolumn{2}{|c|}{ Potassium $\left(\mathrm{kg} \mathrm{ha}^{-1}\right)$} \\
\hline & Grain & Stover & Grain & Stover & Grain & Stover \\
\hline \multicolumn{7}{|c|}{ Plant populations (plants ha ${ }^{-1}$ ) } \\
\hline $\mathrm{P}_{1}-1,11,111\left(45 \times 20 \mathrm{~cm}^{2}\right)$ & 86.3 & 64.3 & 17.8 & 20.4 & 21 & 72 \\
\hline $\mathrm{P}_{2}-83,333\left(60 \times 20 \mathrm{~cm}^{2}\right)$ & 91.0 & 56.0 & 20.6 & 19.0 & 28 & 81 \\
\hline $\mathrm{P}_{3}-66,666\left(75 \times 20 \mathrm{~cm}^{2}\right)$ & 76.0 & 41.0 & 15.7 & 14.4 & 18 & 59 \\
\hline $\mathrm{SEm} \pm$ & 2.49 & 1.92 & 0.47 & 0.59 & 1.31 & 2.70 \\
\hline $\mathrm{CD}(p=0.05)$ & 7.32 & 5.66 & 1.4 & 1.7 & 3.9 & 8.2 \\
\hline \multicolumn{7}{|l|}{ Nitrogen levels $\left(\mathrm{kg} \mathrm{ha}^{-1}\right)$} \\
\hline $\mathrm{N}_{1}-120$ & 56 & 46.1 & 13.57 & 13.03 & 20 & 72 \\
\hline $\mathrm{N}_{2}-170$ & 72.6 & 55.2 & 15.81 & 16.39 & 28 & 80 \\
\hline $\mathrm{N}_{3}-220$ & 92.2 & 64.2 & 18.6 & 17.41 & 34 & 88 \\
\hline $\mathrm{N}_{4}-270$ & 112.1 & 70.2 & 20.5 & 19.7 & 41 & 96 \\
\hline $\mathrm{SEm} \pm$ & 2.88 & 2.22 & 0.54 & 0.68 & 1.52 & 2.40 \\
\hline $\mathrm{CD}(p=0.05)$ & 8.4 & 6.5 & 1.6 & 2.0 & 4.4 & 7.1 \\
\hline \multicolumn{7}{|l|}{ Interaction $(\mathrm{P} \times \mathrm{N})$} \\
\hline $\mathrm{SEm} \pm$ & 4.99 & 3.85 & 0.94 & 1.19 & 2.8 & 4.6 \\
\hline $\mathrm{CD}(p=0.05)$ & NS & NS & NS & NS & NS & NS \\
\hline
\end{tabular}

cob and green fodder yield. Similar findings were reported by Sahoo and Mahapatra (2007); (Sunitha et al., 2011); Bhatt (2012).

Statistically analysed data on nutrient uptake $\left(\mathrm{kg} \mathrm{ha}^{-1}\right)$ furnished in table 2 revealed that differences in nitrogen uptake were significantly influenced by planting densities and nitrogen levels. But, their interaction was not significant.

\subsection{Response equation for nitrogen}

The multiple regression studies describe the relationship between green cob yield $(Y)$ and applied nitrogen $(\times)$ showed a curvilinear trend expressed as a second degree polynomial (Figure 1). The predicted yield worked out from quadratic function showed very high closeness to the observed data as evidenced from very high value of $\mathrm{R}^{2}(0.99)$. The current recommended dose of nitrogen to sweet corn i.e., $120 \mathrm{~kg} \mathrm{~N} \mathrm{ha}^{-1}$ might not be sufficient and the yield potential of sweet corn can be realized by further additions of more nitrogen even beyond $270 \mathrm{~kg} \mathrm{~N} \mathrm{ha}^{-1}$. So, prediction of optimum nitrogen dose within the levels of nitrogen tried in this experiment is not possible. The analysis of the data clearly suggests that a few higher doses of nitrogen need to be tried in order to fix an optimum dose of nitrogen to sweet corn during rabi. Gulgun Oktem and Abdullah Oktem (2005) also reported response of sweet corn to higher level of nitrogen even up to $350 \mathrm{~kg} \mathrm{~N} \mathrm{ha}^{-1}$ which was at par with $300 \mathrm{~kg} \mathrm{~N} \mathrm{ha}^{-1}$. The response of yield of sweet corn to higher nitrogen levels was also reported by Akintoye and Kintomo (2011); Bhatt (2012); (Singh et al., 2012).

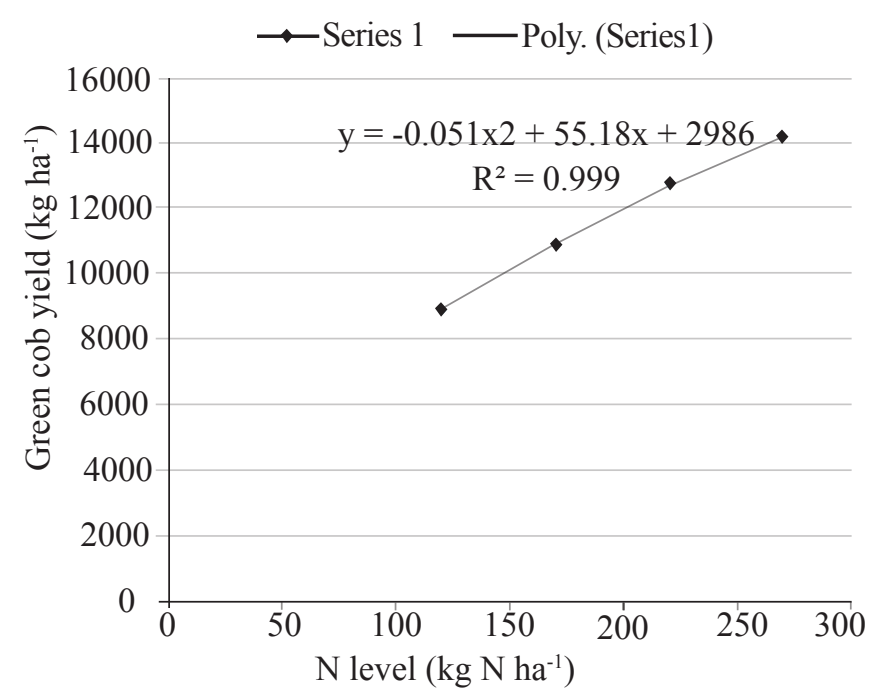

Figure 1: Yield as a function of applied Nitrogen

\subsection{Economics}

Perusal of data on economics (Table 3 ) indicated that irrespective of planting density, the enhancement in nitrogen application increased the gross, net returns and returns per rupee of investment (B:C ratio); (Singh et al., 2012). The highest gross, net returns and returns rupee ${ }^{-1}$ investment (B:C ratio) were obtained at 83,333 plants $^{-1} a^{-1}$ followed by 66,666 plants ha ${ }^{-1}$. The highest net income (₹ 199635) and B:C ratio (4.57) was obtained at planting density of 83,333 plants $\mathrm{ha}^{-1}$ $\left(\mathrm{P}_{2}\right)$ with application of $270 \mathrm{~kg} \mathrm{~N} \mathrm{ha}^{-1}$ followed by $220 \mathrm{~kg} \mathrm{~N}$ $\mathrm{ha}^{-1}$ due to higher green cob yield. Kumar (2009) also reported 
Table 3: Cost of cultivation, gross returns, net returns and B:C ratio of sweet corn as influenced by varying plant densities and nitrogen rates

\begin{tabular}{lcccc}
\hline $\begin{array}{l}\text { Treatment } \\
\text { combina- } \\
\text { tions }\end{array}$ & $\begin{array}{c}\text { Cost of } \\
\text { cultivation } \\
\left(₹ \text { ha }^{-1}\right)\end{array}$ & $\begin{array}{c}\text { Gross } \\
\text { returns } \\
\left(₹ \text { ha }^{-1}\right)\end{array}$ & $\begin{array}{c}\text { Net } \\
\text { returns } \\
\left(₹ h^{-1}\right)\end{array}$ & B:C ratio \\
\hline $\mathrm{P}_{1} N_{1}$ & 48097 & 112495 & 64398 & 1.34 \\
$\mathrm{P}_{2} N_{2}$ & 48710 & 132136 & 83426 & 1.71 \\
$\mathrm{P}_{3}$ & 49330 & 150837 & 101507 & 2.06 \\
$\mathrm{P}_{3}$ & 49946 & 154886 & 104940 & 2.10 \\
$\mathrm{P}_{4} N_{1}$ & 41827 & 150220 & 108393 & 2.59 \\
$\mathrm{P}_{2}$ & 42440 & 182739 & 140299 & 3.31 \\
$\mathrm{P}_{2}$ & 43060 & 215483 & 172423 & 4.00 \\
$\mathrm{P}_{3}$ & 43676 & 243311 & 199635 & 4.57 \\
$\mathrm{P}_{4}$ & 38027 & 104379 & 66352 & 1.74 \\
$\mathrm{P}_{1}$ & 38640 & 131997 & 93357 & 2.42 \\
$\mathrm{P}_{2}$ & 39260 & 153457 & 114197 & 2.91 \\
$\mathrm{P}_{3}$ & 39876 & 180696 & 140820 & 3.53 \\
\hline
\end{tabular}

the maximum net returns and returns rupee ${ }^{-1}$ investment (3.02) at planting density of 83,333 plants ha ${ }^{-1}$ over 66,666 and $1,11,111$ plants ha- ${ }^{-1}$. The lowest net returns (₹ $64398 \mathrm{ha}^{-1}$ ) and $\mathrm{B}: \mathrm{C}$ ratio (1.34) were noticed at higher planting density $\left(\mathrm{P}_{1}\right)$ with application of $120 \mathrm{~kg} \mathrm{~N} \mathrm{ha}^{-1}$ might be because of higher cost of cultivation and lesser green cob and green fodder yield. Lower net returns obtained at $\mathrm{P}_{3}\left(66,666\right.$ plants ha $\left.^{-1}\right)$ were due to lower yields whereas, with $\mathrm{P}_{1}\left(1,11,111\right.$ plants ha $\left.{ }^{-1}\right)$, it was due to more cost incurred in cultivation of sweet corn.

\section{Conclusion}

Under prevailing agro-climatic conditions, sweet corn variety "Sugar-75" grown with the plant density of 83,333 plants ha-1 and fertilized with $270 \mathrm{~kg} \mathrm{~N}^{-1}$ proved most efficient and economically profitable.

\section{References}

Akintoye, H.A., Kintomo, A.A., 2011. Effect of nitrogen on yield and yield components of sweet corn in savanna regions of Nigeria. Proceedings of First All African
Horticultural Congress, Acta Horticulturae 911, 157-161.

Area and production of Maize in India, GoI, 2012-13. Available from http://www.indiastat.com/agriculture/2/ cereals : millets/963995/maize/17199/stats.aspx.

Arvadiya, L.K., Raj, V.C., Patel, T.U., Arvadiya, M.K., 2012. Influence of plant population and weed management on weed flora and productivity of sweet corn. Indian Journal of Agronomy 57(2), 162-167.

Kumar, A., 2009. Production potential and nitrogen use efficiency of sweet corn (Zea mays) as influenced by different planting densities and nitrogen levels. Indian Journal of Agricultural Sciences 79(5), 351-355.

Bhatt, P.S., 2012. Response of sweet corn hybrid to varying plant densities and nitrogen levels. African Journal of Agricultural Research 7(46), 6158-6166.

Coldwell, A.C., 1960. The influence of various nitrogen carriers on the availability of fertilizer phosphorus to plants. International Congress of Soil Science 3, 517-525.

Oktem, A.G., Oktem, A., 2005. Effect of nitrogen and intra row spaces on Sweet corn (Zea mays sachharata Sturt) ear characteristics. Asian Journal of Plant Sciences 4(4), 361-364.

Jackson, M.L., 1973. Soil chemicals analysis. Prentice Hall of India Private Limited, New Delhi.

Oktem, A., 2005. Response of sweet corn to nitrogen and intra row spaces in semi-arid region. Pakistan Journal of Biological Sciences 8(1), 160-163.

Sahoo, S.C., Mahapatra, P.K., 2007. Yield and economics of sweet corn as affected by plant population and fertility levels. Indian Journal of Agronomy 52(3), 239-242.

Singh, U., Saad, A.A., Ram, T., Chand, L., Mir, S., Aga, F.A., 2012. Productivity, economics and nitrogenuse efficiency of sweet corn (Zea mays sachharata) as influenced by planting geometry and nitrogen fertilization. Indian Journal of Agronomy 57(1), 43-48.

Sunitha, N., Reddy, M., Srinivasulu Reddy, D., 2011. Influence of planting pattern and weed control practices on weed growth, nutrient uptake and productivity of sweet corn (Zea mays L). Crop Research 41(1,2 \& 3), 13-20. 